\title{
Determinants Stunting of School Children in Developing Countries
}

\author{
Wardani Putri Sari ${ }^{*}$, Pujonarti Siti Arifah ${ }^{1}$ \\ ${ }^{1}$ Faculty of Public Health, Universitas Indonesia, Depok, Indonesia \\ *Corresponding author.Email: putrisari.72@ui.ac.id, arifah_pujonarti@yahoo.com
}

\begin{abstract}
Introduction: Stunting is one of the main nutritional problems caused by malnutrition in children include schoolchildren. Adequate nutrition consumption of children can influence intelligence, motor and psycomotoric developments. Defines determinant is needed to identified of effective interventions. Purpose: The purpose of this systematic review is to find and determine cause stunting of schoolchildren in developing countries Method: This systematic review was conducted using the Preferred Reporting Items for Systematic reviews and Meta-Analysis (PRISMA) guidelines. Articles were searched by using PubMed, Science direct, Google Scholar and Wiley Online database. Critical appraisal was conducted using Centre for EvidenceBased Medicine (CEBM). Result: Twentyfour article were include studies about urban or rural schoolchildren, double burden, body composition, consumption and food security in developing countries are determinants stunting of schoolchildren. Consumption and sosiodemographics were some of the major factors contributing to stunting of schoolchildren in some countries. Conclusions and Recommendation: Determinants stunting of schoolchildren based on this review are consumption and sociodemographic. Improving nutritional status and consumption especially for schoolchildren are needed to understand the comparative effectiveness stunting prevention of schoolchildren in developing countries.
\end{abstract}

\section{Keywords: determinant, stunting, schoolchildren, develophing countries}

\section{INTRODUCTION}

Health is important in supporting and enhancing human resources. Good human resources refer to the Human Development Index (HDI), there are three determinants of HDI quality, namely the level of education, health and welfare. Health plays an important role in supporting the sustainability of life, related to nutrition which is directly influenced by daily intake.

One of the nutritional problems caused by a lack of macro and micro nutrients is stunting. The World Bank in 2006 also stated that stunting which is chronic malnutrition that occurs in the womb and during the first two years of a child's life can result in low intelligence and a decrease in physical capacity which ultimately leads to a decrease in productivity, a slowdown in economic growth and an extension of poverty.

In an article, World bank stated that out of a population of 252 million, more than 28 million Indonesians (11\%) live below the poverty line, according to a study conducted by Sinaga which states that family income variables are related to children's nutritional status [1]

Inadequate intake of nutrients will affect health, especially for children. Children who experience chronic malnutrition will influence intelligence, psychomotor and motor developments. So to reduce focus and learning achievement in school children and reduce work productivity as adults.
During school age, height and weight growth increase, but the speed is relatively stable. Based on the results of the Basic Health Research [2], the prevalence of short-age school-age children in Indonesia was found to be $30.7 \%$. This is in line with the prevalence of stunting in toddlers in 2013 as much as $37.2 \%$ [2].

Some important factors that can affect the incidence of stunting in school children are the intake of nutrients consumed through food, infectious diseases that can interfere with health, social demographics, food availability, socio-economic and other factors that indirectly affect the nutritional status of school children.

Stunting does not only occur in Indonesia, some other developing countries also experience a variety of nutritional problems, including the problem of malnutrition followed by over nutrition problems. By reviewing the results of research on stunting from various countries, it is hoped that it will produce various information about the causes of stunting and can be a way of preventing and controlling them, so that they can be applied as policies nationally.

\section{METHODS}

This review aims to obtain data on the causes of stunting in school children. Assessment of nutritional status was seen from the Body Mass Index (BMI) or by comparison of body weight according to height. 


\subsection{Search Strategy}

This systematic review was conducted using the Preferred Reporting Items for Systematic reviews and Meta-Analysis (PRISMA) guidelines.

The article used is an article that contains full text (full text). We searched by using Pubmed, Sciencedirect, Wiley Online Library and Google scholar database online. The first search is done by entering the keyword "determinant", the second word is "stunting" and the third word is " schoolchildren" and "develophing countries" were published between 2000 to 2017.

\subsection{Selection of Studies}

Critical appraisal was conducted using Centered for Evidence-Based Medicine (CEBM) for assessment quality of an articles.

The inclusion criteria for articles are in English, focused in schoolchildren aged 6-19 years, in developing countries, analyzed determinant of stunting such as consumption, sanitation, economic, household characteristics and an articles published in the last five years. Exclusion criteria are journals that contain a history of chronic diseases.

\subsection{Data Extraction}

We filter all publications by reading titles and abstract. In the final stage of screening, we read fulltext of the remaining articles. The summary of the selected studies were recorded, include authors, year of publication, population or age of children, determinant of stunting and results of his research.

\section{RESULT}

For Articles that have been searched online by the PRISMA method found 511 articles on stunting in school children. After that the article is filtered again by searching which articles are the same from the four online databases, until the number decreases to 393. Abstracts from the 194 articles are read and scanned again based on inclusion and exclusion criteria. After further screening, 24 articles will be analyzed. The article selection process can be seen in the following diagram:

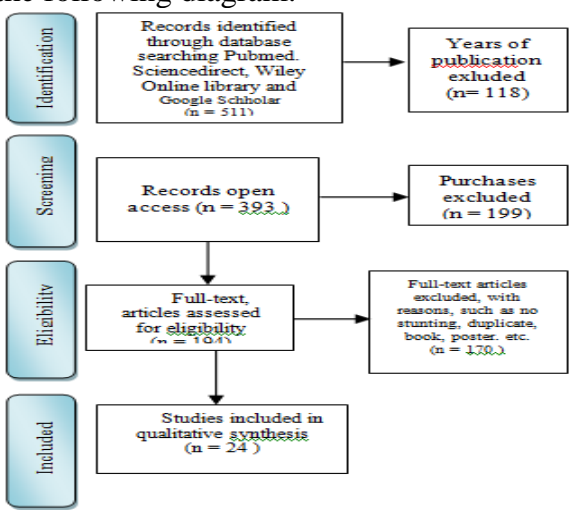

Figure 1: Preferred Reporting Items for Systematic Review and Meta-Analysis

\subsection{Literature Search}

The literature search outlined in method identified 511 potential articles, including year of publication more than 2000 to 2017. We identified 393 articles that potentially met all criteria as a result of title and abstract screening. Fulltext articles excluded with reasons such as no stunting, book, short report etc were 194 articles. The article search results obtained nineteen articles that could be analyzed.

All of the studies reviewed were cros-sectional in design. Ten of them are articles from Indonesia. Most studies reported on all nutritional status, not only stunting but also overweight, wasting and underweight. The articles analyzed sosiodemographic included age, sex, and ethnicity. Sosioeconomic characteristic included income, parental education, parental occupation and others. And environmental factors of schoolchildren as household characteristics contained stunting in rural or urban school children such as in Indonesia, Egypt, Nepal, Ethiopia, and Argentina. Three articles from Indonesia, Palestine and Northern Ecuador discussed dual nutrition issues, one article on body composition, consumption and vulnerability food from Indonesia, Brazil, Tanzania and China.

\subsection{Sosiodemographic Characteristics}

In the 8 sample studies, most articles discuss sociodemographies where school children who live in rural areas tend to experience stunting compared to children who live in cities. This is due to family characteristics, such as the education of mothers and fathers who are still lacking, income and low employment of parents in the research conducted by Herrador[3], [5], [8]. The prevalence of malnutrition was significantly higher in rural than in urban communities (53\%) [5]. In the other hand, there were several differences between children living in rural and urban settings including child health status, behavior and dietary habits.

\subsection{Consumption}

We identified 10 articles analyzed the consumption variable also affects stunting in school children. A study in Egypt indicated that stunted children was significanty higher in participants with poultry consumption less than three times per week $45,9 \%$ dan infrequent fruit consumption $37,8 \%$ [3]. In addition to consuming foods containing macro nutrients such as carbohydrates, protein and fat, the intake of various vitamins and minerals also affects the nutritional status of school children. School children who consume less food containing macro nutrients will indirectly experience micronutrient deficiencies. Research conducted by Agusto. Explained that children who experience $2 x$ nutritional deficiencies are higher in children who consume less vegetables and fruits[9], [16].

\subsection{Sosioeconomic characteristics}

In addition, consumption is also influenced by food insecurity in the area, as in Shen's research, which explains that food insecurity that occurs in an area is strongly associated with malnutrition because food that 
is not enough is eaten in two days. Food insecurity is also caused by low socio-economic conditions. Low-income parents are unable to meet their daily food needs, so that it affects children's nutritional status[10], [20], [21].

Suharidewi in his research companies found that girls shorter than men and some are there who have more nutrition. While Houck explained that in obese girls there is an increase in adipose in the circumference of the arms and triceps muscle. So that it can be concluded that editing is not only the only nutritional problem that must be addressed comprehensively, other nutritional problems that are increasing are over nutrition problems, or commonly called the double burden. This nutritional problem occurs because of poor diet and lack of physical activity, especially in school children[15].

Massad concluded in his research that the prevalence of stunting in Palestine was $7 \%$ and $12 \%$ overweight. Most occur in boys, who have mothers who do not work and nutrient intake that is less strongly associated with underweight[11]. While leisure time filled with watching TV is one of the factors associated with obesity. Physical activity that is less common in children up to adolescents, because some of their diants lack exercise. So that in order to overcome this problem various efforts are needed to prevent the double nutrition problem.

\section{CONCLUSIONS}

Determinants stunting of schoolchildren based on this review are consumption, sosiodemographis, sosioeconomic, in developing countries. The factor such as consumption, sociodemography and socioeconomic is important to reduce stunting in household. Improving nutritional status and consumption for schoolchildren are needed to understand the comparative effectiveness stunting of prevention for schoolchildren in developing countries.

\section{ACKNOWLEDGMENTS}

The authors are grateful to Padang State University and the supervisors in Faculty of Public Health at the University of Indonesia for motivation in this review.

\section{REFERENCES}

[1] M. sari Sinaga, "Universitas Sumatera Utara," 2017. Badan Penelitian dan Pengembangan Kesehatan, "Riset Kesehatan Dasar (RISKESDAS) 2013,” Lap. Nas. 2013, pp. 1-384, 2013.

[2] W. Y. A. Wahed, S. K. Hassan, and R. Eldessouki, "Malnutrition and Its Associated Factors among Rural School Children in Fayoum Governorate , Egypt," vol. 2017, 2017.

[3] B. Amatya and N. Shrestha, "Prevalence of Malnutrition in a Rural Residential Sanskrit School in," vol. 56, no. 3, pp. 153-158, 2017.

[4] Z. Herrador et al., "Cross-Sectional Study of Malnutrition and Associated Factors among
School Aged Children in Rural and Urban Settings of Fogera and Libo Kemkem Districts , Ethiopia," vol. 9, no. 9, pp. 1-12, 2014.

[5] K. Houck et al., "The Effects of Market Integration on Childhood Growth and Nutritional Status: The Dual Burden of Under- and OverNutrition in the Northern Ecuadorian Amazon," vol. 000, no. October 2012, 2013.

[6] M. Garraza, "Malnutrition and Body Composition in Urban and Rural Schoolchildren: A Crosssectional Study in San Rafael , Mendoza ( Argentina )," vol. 00, no. May, 2016.

[7] O. Comandini, G. Carmignani, A. Cipriano, G. Carmignani, D. Tiba, and E. Marini, "Crosssectional and longitudinal analysis of nutritional status of school-children from Bumbire Island ( United Republic of," no. May 2017, pp. 1-5, 2018.

[8] R. A. Augusto, F. Cobayashi, and M. Augusto, "Associations between low consumption of fruits and vegetables and nutritional de fi ciencies in Brazilian schoolchildren," vol. 18, no. 5, pp. $927-$ 935, 2014.

[9] X. Shen, X. Gao, W. Tang, X. Mao, J. Huang, and W. Cai, "Food insecurity and malnutrition in Chinese elementary school students," no. 2015, pp. 952-958, 2018.

[10] S. Massad et al., "Double Burden of Undernutrition and Obesity in Palestinian Schoolchildren: A Cross-Sectional Study," vol. 37, no. 2, pp. 144-152, 2016.

[11] T. S. Siregar, "Gambaran pola makan siswa stunting di smp negeri 1 dolok masihul tahun 2017," 2018.

[12] M. I. Pintubatu, "Gambaran kebiasaan makan dan indeks prestasi belajar anak SD yang mengalami stunting di SDN Berastagi tahun 2017," 2017.

[13] N. Made, A. Suastiti, and N. K. Sutiari, "Community Health," vol. I, no. 1, pp. 37-42, 2013.

[14] I. G. Agung, T. Suharidewi, and G. N. I. Pinatih, "Gambaran Status Gizi Pada Anak Tk Di Wilayah Kerja Upt Kesmas Blahbatuh Ii Kabupaten Gianyar Tahun 2015," vol. 6, no. 6, pp. 1-6, 2017.

[15] E. Anggraeni, "Hubungan Tingkat Kecukupan Energi Dan Protein Dengan Status Gizi Pada Anak Kelas V Sekolah Dasar Islam Terpadu," pp. 180 184, 2017.

[16] N. A. Z and Umroh, "Pola asuh orang tua dengan konsep diri anak stunting di sekolah dasar negeri 1 ngerong gempol pasuruan," vol. 7, no. 2, pp. 42 53, 2015 .

[17] R. Mandriyarini, Sedentary Lifestyle Sebagai Faktor Risiko Kejadian Obesitas Pada Remaja Stunted Usia 14-18 Tahun Di Kota Semarang. 2016. 
[18] M. M. Tarigan, "Pola makan dan status gizi siswa yayasan perguruan al-azhar medan 2017 skripsi penelitian,” 2017.

[19] M. R. Mukherjee, L. C. S. Chaturvedi, and C. R. Bhalwar, "Determinants of nutritional status of school children," Med. J. Armed Forces India, vol. 64, no. 3, pp. 227-231, 2007.

[20] M. U. Mushtaq, S. Gull, U. Khurshid, U. Shahid, and M. A. Shad, "Prevalence and sociodemographic correlates of stunting and thinness among Pakistani primary school children Prevalence and socio-demographic correlates of stunting and thinness among Pakistani primary school children," vol. 790, no. October, 2011.

[21] E. J. Chesire, A. S. S. Orago, L. P. Oteba, and E. Echoka, "Determinants Of Under Nutrition Among School Age Children In A Nairobi PeriUrban Slum," no. October, 2008.

[22] M. Sekiyama, "Physical growth and diets of school children: Trends from 2001 to 2015 in rural West Java , Indonesia," no. August, 2017.

[23] B. Alipour et al., "Child-Specific Food Insecurity and Its Sociodemographic and Nutritional Determinants among Iranian Schoolchildren Child-Specific Food Insecurity and Its Sociodemographic," vol. 0244, no. February, 2016.

[24] M. Wolde, Y. Berhan, and A. Chala, "Determinants of underweight, stunting and wasting among schoolchildren,” pp. 1-9, 2015. 